\title{
When I'm 64: What do New Zealanders want in a retirement income policy?
}

\author{
Joey Au, Andrew Coleman and Trudy Sullivan¹
}

\section{Abstract}

It is difficult to choose policies when people have diverse preferences over outcomes and many alternative policy settings are available. To do this well, policymakers must understand underlying preferences and rank policies according to these preferences. In this paper, we use multi-criteria decision analysis techniques to understand the relative attractiveness of retirement policy reforms in New Zealand. Using a nationally representative sample, we estimate individual preferences over seven aspects of retirement policy, characterise the diversity of these preferences, and rank three different policy options. We find that a policy which raises taxes to prefund the government retirement income scheme would be supported by a majority of people of all ages and income groups, and would be much more popular than a policy that

\footnotetext{
1 andrew.coleman@otago.ac.nz, The Department of Economics, University of Otago; joey.au@mbie.govt.nz, Ministry of Business, Innovation and Employment, New Zealand; Trudy.Sullivan@otago.ac.nz, The Department of Preventative and Social Medicine, University of Otago. We would like to thank Diane Maxwell, Malcolm Menzies, Richard Thompson, Kathryn Maloney and Tania Werder at the Commission for Financial Capability for their advice and support while the project was undertaken. Several staff at the New Zealand Treasury assisted in the project. We would particularly like to thank Girol Karacaoglu, Gabriel Makhlouf, Chris Ball, Matthew Bell, Deborah Cuzens, Margaret Galt, Bryan McDaniel and Paul Rodway. We are indebted for the assistance provided by the staff of 1000Minds, Paul Hansen and Franz Ombler, throughout the project and for comments on the paper. We also wish to thank the staff of Colmar Brunton, particularly Leilani Liew, for their help in fine-tuning and implementing the questionnaire. We are grateful for the time the members of focus groups in Dunedin, Wellington and Auckland spent with us discussing their views, including Atene Andrews and the Hikoikoi Kaumātua group in Petone. Lastly, we wish to thank seminar participants and discussants at the University of Otago, the University of Auckland and the Western International Economics Conference, with particular thanks to Arthur Grimes from Motu. We also wish to thank Matt Benge, Norman Gemmell, Nicola Kirkup, David Law, Trinh Le and Jacques Poot for their helpful comments and suggestions. This project received financial support from the New Zealand Treasury, Wellington, and the Commission for Financial Capability, Auckland, New Zealand.
} 
raises the age of eligibility. The results suggest multi-criteria decision analysis has considerable potential to help policymakers develop policies that are aligned with people's preferences.

\section{Introduction}

Governments use a variety of methods including public opinion polling and focus group discussions to elicit their constituents' preferences (Lees-Marshment, 2015). These methods typically require a trade-off between the complexity of the issues that are investigated and the statistical validity of the resultant findings. In response to these trade-offs, researchers in the health, environment and energy fields sometimes use multi-criteria decision analysis techniques to obtain systematic evidence about people's preferences (Devlin and Sussex, 2011; Gamper and Turcanu, 2007; Mendoza and Martins, 2006). While these techniques are designed to analyse the relative importance of different aspects of complex problems (Arrow and Raynaud, 1986; Belton and Stewart, 2002), they have yet to be used to study major public finance problems.

This paper reports the findings of an online multi-criteria decision survey conducted by the New Zealand Treasury to investigate public preferences about retirement income policy reforms. The paper (i) investigates the relative importance of seven aspects of retirement income policies to a representative sample of New Zealanders, (ii) documents the diversity of their policy preferences in a systematically quantifiable manner, and (iii) ranks three different retirement income policies from an individual welfare perspective.

Several other retirement income surveys have asked respondents to make explicit trade-offs between two aspects of a policy, for example whether they would be prepared to raise taxes to provide larger retirement incomes (e.g. Boeri, BoerschSupan and Tabellini (2002) for Italy and Germany; Van Els et al. (2004) for the Netherlands; or Fourati and O'Donoghue (2009) for Ireland). This study improves their survey methodologies in three ways. First, rather than surveying respondents about their attitudes towards complex policy packages, respondents are asked to make pairwise comparisons over particular features of policy packages, decisions that are easier to make. Secondly, the technology enables us to estimate a complete ranking of the relative importance of each criterion for each person, which previous studies have been unable to do. For example, we estimate the relative importance of the pension amount and the age of eligibility, the pension amount and future tax rates, and the pension amount and the means-testing regime, not just one of these combinations. Thirdly, the technique allows us to estimate each respondent's preferences over large numbers of policy packages comprised of 
different combinations of simple policy features rather than the small number of policies included in traditional surveys. Thus the technique can be used to inform the development of new policies.

The survey approach proved to be very successful and suggests multi-criteria analysis is a promising technique to improve the ways governments design policies. One of our main findings, for instance, is that a substantial majority of respondents would opt for an increase in current taxes if this could prevent even larger tax increases on future generations. We also find that there is widespread opposition to means-testing, and that there are strongly divergent preferences over the appropriate eligibility age for New Zealand Superannuation. These findings enable us to conclude that a policy combination that raises the eligibility age for New Zealand Superannuation and reduces future tax increases would be supported by few and opposed by many. However, a policy that more aggressively prefunds the government pension by immediately raising taxes and investing surplus funds would be supported by a majority of people of all ages and income levels.

\section{The retirement income survey}

\subsection{Multi-criteria decision analysis}

Multi-criteria decision analysis has been developed to assist people make complex choices over outcomes that involve multiple criteria or dimensions in an explicit, consistent and transparent way. This paper uses the PAPRIKA (Potentially All Pairwise Rankings of all Possible Alternatives) method implemented through 1000 Minds software to estimate a respondent's preference ranking over a set of criteria (Hansen and Ombler, 2008; Ombler and Hansen, 2012). Respondents are presented with a series of hypothetical choices in an online survey, each of which involves scenarios that combine a highly-ranked category from one criterion and a lowly-ranked category from another, so that each choice requires a trade-off to be made. Figure 1 is an example of a trade-off question from the survey. Respondents choose the combination of criteria they prefer from the two alternative scenarios: the one on the left retains the age of eligibility at 65 but requires current taxes to increase by 2 per cent; the one on the right keeps current taxes the same, but raises the age of eligibility to 67. A respondent chooses his or her preferred combination, or indicates that they are indifferent between the two scenarios. Once the selection is made, the respondent is presented with another hypothetical scenario using categories from two randomly selected criteria. The process is repeated until the algorithm has enough information to estimate a complete preference ranking over the criteria. 


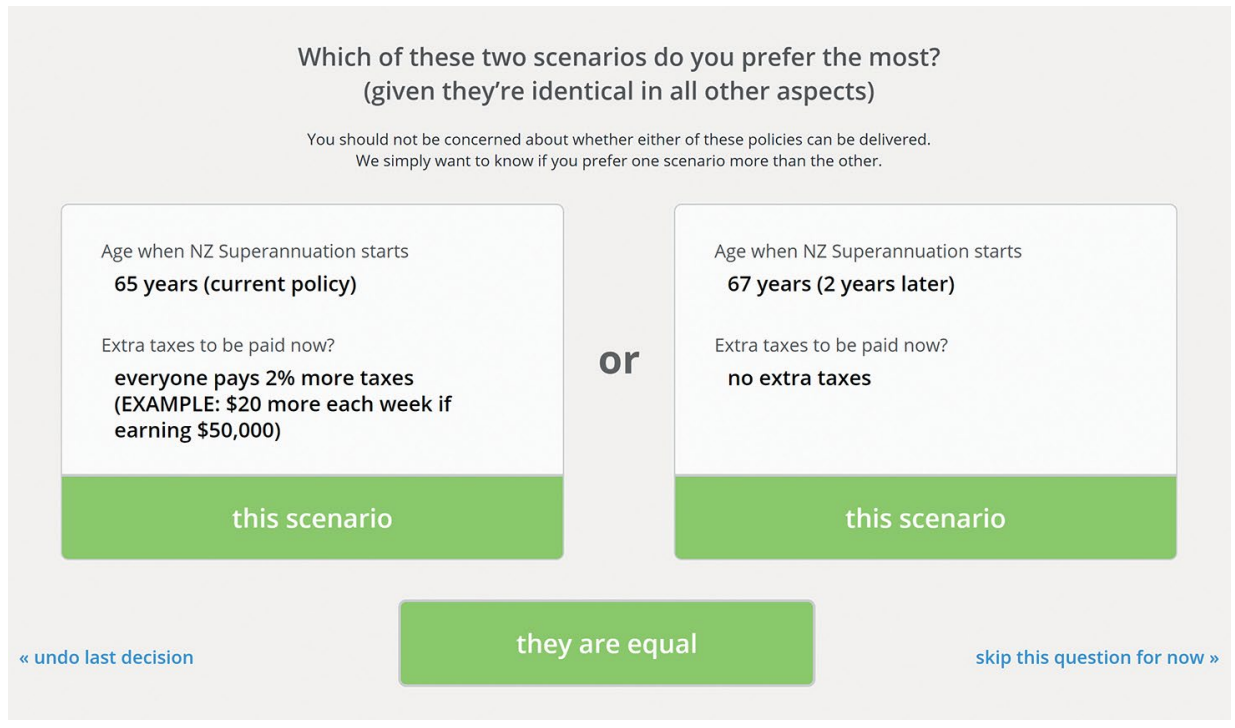

Figure 1. Example of a trade-off question

Source: Authors' survey using 1000Minds software.

Each criterion in the survey is represented by categories that are ranked from lowest to highest according to the benefits they provide a person. For example, if the categories for the 'age of eligibility' criterion are ' 65 years' and ' 67 years', the category ' 65 years' would be ranked higher than ' 67 years' as a person receives a pension for more years, and can retire earlier. The PAPRIKA method reduces the number of questions that respondents answer by automatically excluding dominated pairwise comparisons and by imposing transitivity to implicitly answer other questions.

The PAPRIKA algorithm assumes each respondent's preferences can be represented by a cardinal utility function defined over the survey criteria, and it estimates a set of utility weights for each criteria-category that is consistent with the way they answer the survey. ${ }^{2}$ For example, if a person prefers a pension of $\$ 360$ per week from age 65 over a pension of $\$ 390$ per week from age 67, the sum of the weights for ' $\$ 360$ per week' and ' 65 years' exceeds the sum of the weights for ' $\$ 390$ per week' and ' 67 years'. Since the weights are inversely proportional to the rank of each criteria when there are only two categories for each criterion, in this paper we usually present the results in terms of the rank of each criterion from 1 (important) to 7 (unimportant), noting that the most important criterion has the highest weight. (Note that all dollar amounts discussed throughout are in New Zealand dollars.)

2 The working paper version of this paper includes a simplified description of the algorithm for those wanting more information. The algorithm is fully described in Hansen and Ombler (2008). 
The weights are used to estimate how individuals rank policies that differ in terms of the outcomes they deliver. The calculation is done in two steps. First, the effect of the policy on each of the criteria is estimated. The policy might increase the age of eligibility to 66 years and increase the amount of the pension to $\$ 375$ per week, for example. Secondly, the effect of the policy on each individual's utility is estimated by adding up the individual's weights for each outcome, using linear interpolation where necessary. For example, if a policy raised the age of eligibility to 66, we would use the average of the weights for ' 65 years' and ' 67 years'. The policy with the highest utility score is deemed to be the individual's preferred policy.

\subsection{New Zealand's government retirement income schemes}

Government retirement income schemes are classified three ways. Tier 1 schemes provide a retirement income funded from general taxation to eligible people irrespective of the amount they contribute during their working-age years. These incomes can be the same for all people (universal) or they can be means-tested. Tier 2 or contributory schemes provide retirement incomes that depend on the amount that people contribute to the scheme during their working-age years. Tier 3 schemes encourage voluntary retirement saving by offering subsidies or lower taxes. New Zealand is one of two OECD countries without a tier 2 scheme. It has a universal tier 1 scheme, New Zealand Superannuation, that is largely funded on a pay-as-you-go basis from general taxation, and a subsidised tier 3 scheme, KiwiSaver, introduced in 2007.

The survey was designed to find out the population's preferences over several policy reforms under discussion at the time of the survey. These potential reforms included: (i) raising the age of eligibility for New Zealand Superannuation; (ii) prefunding New Zealand Superannuation by raising current taxes and investing the proceeds; (iii) introducing a means-test for New Zealand Superannuation; and (iv) introducing a tier 2 compulsory saving scheme.

\subsection{The survey criteria}

The survey criteria listed in Table 1 were chosen after a process involving an extensive review of the retirement income policy literature, the results of a trial survey conducted on a non-representative group of public servants, and discussions with several focus groups. ${ }^{3}$ The number of categories was kept to a minimum to reduce the length of the survey. Each criterion had two category levels that were chosen so that the differences between categories were broadly similar in dollar terms. The baseline

3 The focus groups included students, retirees, women, Māori, Pacific people, disabled people, retirement policy experts and representatives from Grey Power, an advocacy group promoting the welfare of older citizens. 
categories for the age of eligibility (age 65) and the amount of the pension ( $\$ 360$ per week) reflect the parameters of the New Zealand Superannuation scheme in 2014. The second category for the age of eligibility, 67 years, was chosen as it is an age that was often mentioned in contemporaneous public debate. As two years of retirement income is approximately equal to $\$ 30,000$, or $\$ 30$ per week over the average length of time someone receives a pension, the second category of the pension amount was chosen to be $\$ 390$ per week, so that the two criteria could be meaningfully compared. The baseline categories for the current and future tax criteria are the taxes that would be needed to fund New Zealand Superannuation now and in the future if there were no changes to its current structure. The second category reflects the size of the tax increase that would be necessary to support a $\$ 30$ per week increase in the size of the pension, which was calculated to be approximately 2 per cent of personal income. For symmetry we chose to vary current and future taxes by the same amount. Since New Zealand Superannuation is universally provided rather that means-tested, the baseline category was 'No means-testing'. We chose the second category of the means-testing criterion to make the revenue raised by the means-test similar to the revenue saved by raising the age of eligibility.

\section{Table 1. The survey criteria}

\section{The criteria}

Amount of NZ Superannuation everyone receives

- $\quad \$ 360$ a week (current level)

- $\quad$ increases by $\$ 30$ a week to $\$ 390$

Age when NZ Superannuation starts

- 67 years (2 years later)

- 65 years (current policy)

Extra taxes to be paid now?

- $\quad$ everyone pays $2 \%$ more taxes (Example: $\$ 20$ more each week if earning $\$ 50,000$ )

- no extra taxes

Extra taxes the next generation (i.e. not you) has to pay

- $\quad 5 \%$ more taxes (Example: $\$ 50$ more each week if earning $\$ 50,000$ )

- $\quad 3 \%$ more taxes (Example: $\$ 30$ more each week if earning \$50,000)

Will everyone receive the same amount of NZ Superannuation?

- No, people with retirement savings greater than $\$ 200,000$ have their NZ Superannuation reduced by $\$ 60$ per week

- Yes, everyone gets the same NZ Superannuation

The amount of your personal savings to spend or invest when you retire

- 2 years of your average annual income (don't worry how you get this amount)

- 3 years of your average annual income (don't worry how you get this amount)

Savings flexibility

- it is compulsory to save 5\% of your income each week (Example: $\$ 50$ put aside each week if earning $\$ 50,000$ )

- you can save when and how you like

Source: Authors' survey criteria distributed using 1000Minds software. 
One issue that underlies the whole survey is framing. It is well known that the framing of questions can have an enormous effect on survey responses. Some authors such as Bartels (2003) argue that framing effects may be sufficiently crucial to the design of a survey that they fundamentally undermine the use of all surveys as a source of useful information. We - and all other authors who conduct surveys are not so extreme in our views. Nonetheless, it is possible that the relative ranking of the responses in part reflects the way the questions were framed, and that the answers might have been different if they were framed differently.

\section{Survey results and discussion}

\subsection{The sample}

A professional surveying firm, Colmar Brunton, provided the web panel sample, which was conducted in 2014. Respondents typically answered 12 survey questions, and took 5 to 10 minutes to answer the survey. To assuage concern that the respondents may not have understood the surveying technique, the respondents were required to repeat two of the comparison questions at the end of the survey. These comparison questions included one of the most preferred and one of the least preferred criteria, making it easy for someone doing the survey in good faith to answer, while discriminating against respondents who may not have understood the questions or who answered the questions in a random fashion. Over 1,300 people were surveyed, of whom 1,066 or 80 per cent answered both repeated questions consistently. ${ }^{4}$ This success rate provides evidence that the survey procedure was well understood. Respondents who did not answer both additional questions consistently were excluded from the sample. People who answered the survey very quickly were also excluded, as their responses were often inconsistent.

Table 2 provides information about selected economic and demographic characteristics of the survey respondents. The results have been reweighted to take account of the difference between the socio-demographic characteristics of survey respondents and the socio-demographic characteristics of the total population, using weights provided by Colmar Brunton. The reweighting has little effect on the results as the sample is broadly representative of the New Zealand public. The sample of 1,066 is similar in size to the Eurobarometer surveys analysed by

\footnotetext{
4 We also tested the PAPRIKA algorithm transitivity assumption. Consider the two tax criteria 'current taxes' and 'future taxes'. Some respondents compared these two criteria directly, while for others the relative importance of the two criteria is inferred indirectly by applying the transitivity principle to their responses to other questions. The average ranks of the 'direct' and 'indirect' groups should be the same. Of the 63 per cent of respondents who compared the two criteria directly, 66 per cent ranked low future taxes as more important than low current taxes. Of the remaining 37 per cent of respondents, 63 per cent ranked future taxes as more important than current taxes. The similarity of these two numbers in this and other examples suggests the transitivity assumption holds adequately in this survey.
} 
Lynch and Myrskylä (2009), and while it is smaller than some other retirement income surveys it is large enough to generate confidence interval estimates that can discriminate between alternative hypotheses as the intervals are small relative to the scales we are using. ${ }^{5}$ In addition to demographic information, respondents were asked how confident they are that they will have enough money to live comfortably in retirement. Four options were offered: 'Not confident at all', 'Not too confident', 'Somewhat confident' and 'Very confident'. The responses to this question were one of the strongest predictors of an individual's preferences. Of the sample group, 9 per cent said they were 'Not confident at all', while 16 per cent said they were 'Very confident'.

Table 2. Selected economic and demographic characteristics of the survey respondents

\begin{tabular}{|c|c|c|c|c|c|c|c|}
\hline \multicolumn{2}{|l|}{ Gender } & \multicolumn{2}{|c|}{ Age (years) } & \multicolumn{2}{|l|}{ Household income } & \multicolumn{2}{|l|}{ Education } \\
\hline Male & $46 \%$ & $<35$ & $26 \%$ & $<\$ 50,000$ & $32 \%$ & Degree & $48 \%$ \\
\hline \multirow[t]{2}{*}{ Female } & $54 \%$ & $35-64$ & $59 \%$ & $\$ 50,000-\$ 100,000$ & $41 \%$ & Post-sec. school & $20 \%$ \\
\hline & & $65+$ & $15 \%$ & $\$ 100,000+$ & $27 \%$ & High school & $32 \%$ \\
\hline \multicolumn{2}{|l|}{ Ethnicity } & \multicolumn{2}{|c|}{ Employment status } & \multicolumn{2}{|l|}{ Geographical spread } & \multicolumn{2}{|c|}{ Confidence in retirement } \\
\hline European & $76 \%$ & Full-time & $53 \%$ & Auckland & $33 \%$ & Not at all confident & $8 \%$ \\
\hline Māori & $12 \%$ & Part-time & $17 \%$ & Other North Island & $41 \%$ & Not too confident & $27 \%$ \\
\hline Pacific & $6 \%$ & Retired & $15 \%$ & South Island & $26 \%$ & Somewhat confident & $49 \%$ \\
\hline Other & $6 \%$ & Other & $15 \%$ & & & Very confident & $16 \%$ \\
\hline \multicolumn{2}{|c|}{ KiwiSaver member? } & \multicolumn{2}{|l|}{ Children } & \multicolumn{2}{|l|}{ Marital status } & & \\
\hline Yes & $67 \%$ & Yes & $60 \%$ & Married/civil union & $61 \%$ & & \\
\hline No & $32 \%$ & No & $40 \%$ & De facto & $15 \%$ & & \\
\hline Don't know & $1 \%$ & & & Single & $24 \%$ & & \\
\hline
\end{tabular}

Source: Authors' calculations derived from the survey responses.

5 The Eurobarometer surveys surveyed between 1,000 and 1,100 respondents in 15 European countries, and 600 respondents in Luxembourg. Other retirement income surveys have taken place in Ireland, with 326 respondents (Fourati and O'Donoghue, 2009); in the Netherlands, with 1,200 households (Van Els et al., 2004); in the United States, with 1,400 respondents (the General Social Survey; Ponza et al., 1988); in Australia, with 1,600 respondents in three different years (Evans and Kelley (2004)); and in Italy and Germany, with 2,500 respondents in each country (Boeri et al., 2002). 


\subsection{Methodological approach ${ }^{6}$}

A respondent's survey response can be represented by estimated utility weights or by a vector that lists the rank he or she gives to each criterion, for example $x_{i}=(6521$ 473 ). The equivalence of the ranking and utility weighting representations means non-parametric methods can be used to analyse the results. If there is a set of $m$ respondents, $X=\left\{x_{1}, x_{2}, \ldots, x_{m}\right\}$, one measure of their average preferences is the mean preference vector $\bar{x}$ :

$\bar{x}=\frac{1}{m} \sum_{j=1}^{m} x_{j}$

If there are two populations, the difference in their mean preference vectors is an estimate of the differences in their average preferences. We use the Wilcoxon-MannWhitney statistic to test the hypothesis that members of the two groups have the same distribution of preferences over a particular criterion. If the test statistic has a high absolute value, the hypothesis that the two groups have the same distribution of preferences over this criterion can be rejected. We also use the Li and Schucany (1975) statistic to test the hypothesis that the mean preference vectors are the same for all of the criteria, not just each single criterion. ${ }^{7}$

We measure the diversity of preferences of a group by calculating the mean Spearman rank correlation coefficient between all possible pairs of people in the group. To calculate this, we first calculate the Spearman rank correlation between the vectors of two members of a group, $x$ and $y$ : if $n$ is the number of criteria, the correlation coefficient is

$\rho_{x y}=1-\frac{6}{n\left(n^{2}-1\right)} \sum_{i=1}^{n}\left(x_{i}-y_{i}\right)^{2}$

The mean Spearman rank correlation is calculated by calculating the mean Spearman rank correlation for all $m(m+1) / 2$ possible pairs of respondents. This has a value between negative one and one. If a group has uniformly distributed preferences, meaning that each of the vectors is equally likely, it would have a mean Spearman value equal to zero.

\footnotetext{
6 This section is based on Mardin (1995).

7 We also calculated a different set of metrics that correspond to a group's median responses. As these results are qualitatively similar in all respects, we have chosen to only discuss results in terms of mean responses. The other results are available in the working paper version of the paper.
} 


\subsection{The average level and dispersion of preference ranks}

Table 3 shows the mean preference vector for the sample, plus the fraction of the population who ranked each criterion either highest or lowest. (Rank ' 1 ' means the criterion is important; rank '7' means it is unimportant.) There are three key results.

Table 3. Average retirement income preferences in New Zealand $(\mathrm{N}=1,066)$

\begin{tabular}{|l|r|r|r|r|r|r|r|}
\hline Criterion & $\begin{array}{c}1 \\
\text { Pension } \\
\text { amount }\end{array}$ & $\begin{array}{c}\text { Age } \\
65 / 67\end{array}$ & $\begin{array}{c}3 \\
\text { Current } \\
\text { taxes }\end{array}$ & $\begin{array}{c}4 \\
\text { Future } \\
\text { taxes }\end{array}$ & $\begin{array}{c}5 \\
\text { Means } \\
\text { tests }\end{array}$ & $\begin{array}{c}6 \\
\text { Wealth } \\
\text { amount }\end{array}$ & $\begin{array}{c}7 \\
\text { Flexible } \\
\text { savings }\end{array}$ \\
\hline Overall importance & 4 & 3 & 5 & 2 & 1 & 6 & 7 \\
\hline Mean rank & 4.09 & 3.92 & 4.15 & 3.41 & 3.15 & 4.27 & 5.02 \\
\hline \% rank 1 & $7.8 \%$ & $21.2 \%$ & $5.9 \%$ & $12.4 \%$ & $41.7 \%$ & $5.4 \%$ & $9.8 \%$ \\
\hline \% rank 7 & $10.7 \%$ & $15.1 \%$ & $5.3 \%$ & $2.6 \%$ & $14.3 \%$ & $8.8 \%$ & $38.1 \%$ \\
\hline Mean Spearman correlation 0.080 &
\end{tabular}

Source: Authors' calculations derived from the survey responses.

(i) The distribution of preferences. New Zealanders have very diverse preferences about retirement income policies. Nevertheless, while the mean Spearman rank correlation is only 0.08 , the hypothesis that New Zealanders have uniformly distributed preferences can be rejected at the 5 per cent significance level.

(ii) The relative importance of the seven criteria. The mean preference ranks for the different criteria range from a minimum of 3.15 to a maximum of 5.02. The two highest-ranked criteria concern (i) universality/means-testing and (ii) future tax rates. On average, respondents expressed a strong preference for universal rather than means-tested pensions, and were opposed to policies that result in steep increases in taxes on future generations. The lowest-ranked criterion is the flexible saving/ compulsory saving criterion: few people thought saving flexibility provided many advantages relative to a compulsory saving scheme. The other four criteria had mean ranks very close to 4 , the mean value when preferences are uniformly distributed. Three of these criteria - current tax levels, the amount of the pension, and the amount of wealth people have in retirement - were of moderate importance to most people. The fourth criterion, the age of eligibility, had a bimodal distribution.

(iii) The distribution of rank preferences. Figures $2 \mathrm{~A}-2 \mathrm{~F}$ show the entire distributions of the preference rank vectors. Figure $2 \mathrm{~A}$ shows that the 'universality/means-testing' criterion is the most important criterion to the largest number of people. Fortytwo percent of respondents rank universality rather than means-testing as the most important feature of retirement income policy, and an additional 20 per cent rank it as the second or third most important. 
Figure $2 \mathrm{~B}$ shows the distribution of preference ranks for the two tax criteria. Both are 'hump-shaped': they are moderately important but neither the most important nor the least important criteria for most people. The figure shows most people are more opposed to future tax increases than current tax increases: indeed, 65 per cent of all respondents gave (low) 'future taxes' a higher weight than 'current taxes', while only 30 per cent ranked them the other way around. (This split held for all population subgroups.) These responses strongly suggest that there is widespread opposition to policies that impose high costs on future generations.

Figures 2C and 2D show the distribution of preference ranks for two other humpshaped criteria: the benefit of higher pensions, and the benefit of higher retirement savings. These criteria are moderately important to most people with respondents being almost equally divided as to whether they preferred higher pensions or higher retirement savings.

Figure 2E shows the distribution of preference ranks for the flexible saving/ compulsory saving criterion. It has the opposite shape to Figure 2A: there are relatively few people who think saving flexibility is very important, and many who think it is not important. Overall, 38 per cent of respondents indicated that saving flexibility was the least important of all seven criteria, and only 19 per cent indicated it was one of the two most important criteria. This result suggests there would be little opposition to a compulsory saving scheme if it raised the amount of wealth available at retirement, possibly because many people already save this amount.

Lastly, Figure 2F shows the preference ranks for the age of eligibility criterion. It is the only criterion with a bimodal response. Thirty-seven per cent of the respondents indicate it is very important to keep the age of eligibility at 65 (1st or 2nd ranking), and 32 per cent of respondents indicate it is unimportant (6th or 7 th ranking). The criterion is important to people from low-income households, to New Zealanders of Pacific ethnicity, and to those who are not confident about their retirement prospects, but unimportant to people over 65, to New Zealanders of European ethnicity, and to people who are confident about their retirement prospects. 


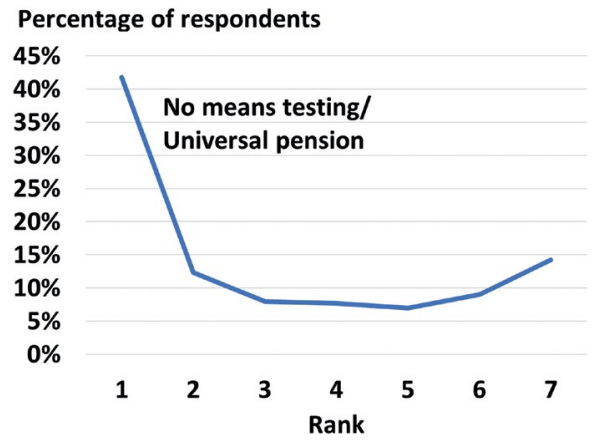

Figure 2A. Universality/No means-testing

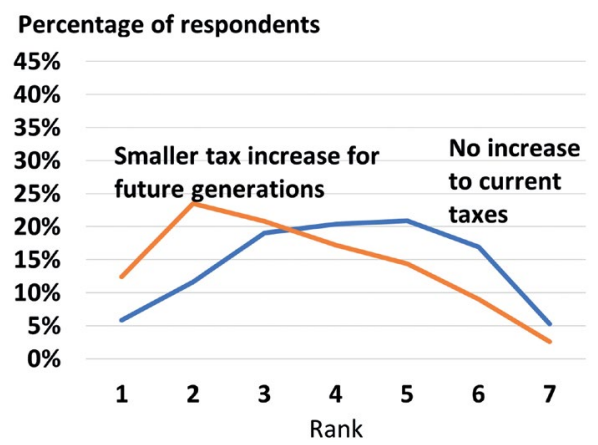

Figure 2B. Current and future taxes

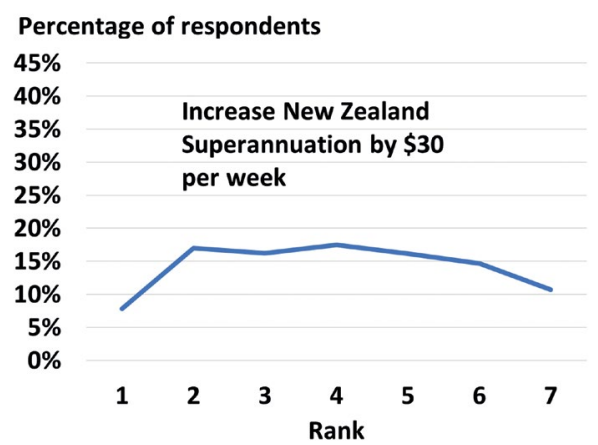

Figure 2C. Pension amount

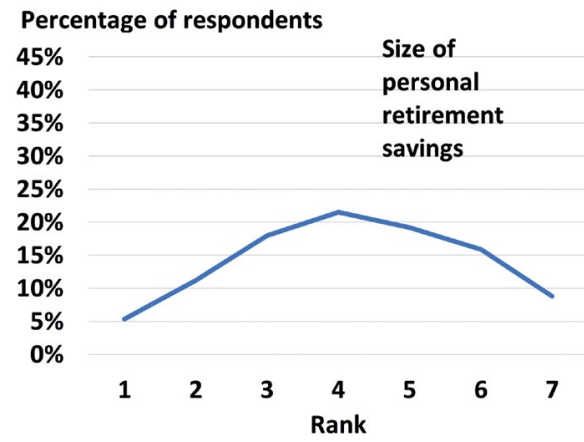

Figure 2D. Wealth amount

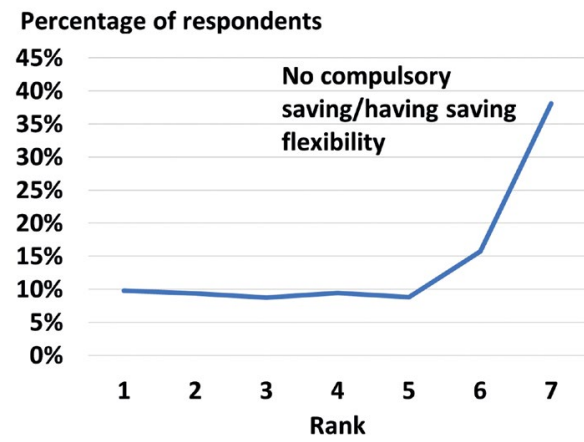

Figure 2E. Saving flexibility/compulsion

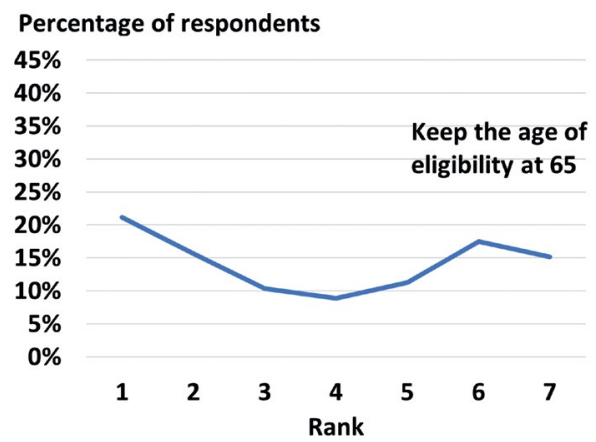

Figure 2F. Age of eligibility

Figure 2. Distribution of preference ranks for the whole survey

Source: Authors' calculations derived from the survey responses. Rank $1=$ highest rank/most important criterion. 


\subsection{Results for population subgroups}

It is natural to ask whether different population subgroups have different preferences. The short answer is that they do, but that these differences, while statistically significant, tend to be small. With one exception (the subgroup of Pacific people, discussed further below), there were few criteria where the mean preference ranks for population subgroups defined in terms of observable characteristics such as age, gender, household income, education or ethnicity differed by more than 0.5 ranks on a scale of 1-7. Indeed, the largest differences between subgroups occurred for groups that self-identified in terms of their expected comfort in retirement rather than for groups that could be identified in terms of measurable characteristics.

The analysis of population subgroups is conducted in two ways. First, we divided the population into subgroups and compared the mean preference ranks for a particular subgroup with all people not in that group: for example, people aged 65 or over versus people aged less than 65 . In each case we calculated the mean rank of each criterion for the two subgroups, and used a Wilcoxon-Mann-Whitney test to test whether the distributions were the same. ${ }^{8}$ Table 4 shows the mean differences for each criterion for various subgroups. These subgroup comparisons do not condition on other factors that may vary across subgroups, and thus do not estimate the marginal effect of a socio-demographic factor on preference ranks. To do this we estimate a fractional multinomial logit model (Table 5), using the entire set of socio-demographic variables as independent variables. This model takes into account the loss of one degree of freedom that occurs when objects are ranked. We estimate the model using the utility function representation in which the rank vectors are converted into a set of normalised weights. As each criterion only has two categories, the weights are equal to the rank divided by 28 , and sum to one. These weights are simultaneously regressed against dummy variables corresponding to each of the socio-demographic variable categories. The regression coefficients indicate how the weight of each criterion depends at the margin on each socio-demographic variable.

8 We also calculated the Li-Schucany test statistic of the hypothesis that the two subgroups have the same mean vector of preferences across all criteria: this was rejected at the 1 per cent level for all groups, and is not reported. 
Table 4. Mean difference by criteria for selected population subgroups

\begin{tabular}{|c|c|c|c|c|c|c|c|c|}
\hline & $\mathrm{N}$ & $\begin{array}{c}1 \\
\text { Pension } \\
\text { amount }\end{array}$ & $\begin{array}{c}2 \\
\text { Age } \\
65 / 67 \\
\end{array}$ & $\begin{array}{c}3 \\
\text { Current } \\
\text { taxes }\end{array}$ & $\begin{array}{c}4 \\
\text { Future } \\
\text { taxes }\end{array}$ & $\begin{array}{c}5 \\
\text { Means } \\
\text { tests }\end{array}$ & $\begin{array}{c}6 \\
\text { Wealth } \\
\text { amount }\end{array}$ & $\begin{array}{c}7 \\
\text { Flexible } \\
\text { savings }\end{array}$ \\
\hline All people & 1,066 & 4.09 & 3.92 & 4.15 & 3.41 & 3.15 & 4.23 & 5.02 \\
\hline \multicolumn{9}{|c|}{ Demographic characteristics } \\
\hline Male & 510 & $-0.23^{*}$ & 0.21 & -0.07 & 0.14 & -0.13 & -0.19 & 0.26 \\
\hline Female & 556 & $0.23^{*}$ & -0.21 & 0.07 & -0.14 & 0.13 & 0.19 & -0.26 \\
\hline Single & 253 & -0.10 & 0.05 & -0.10 & -0.07 & 0.29 & -0.14 & 0.07 \\
\hline Has children & 624 & 0.13 & -0.23 & 0.02 & 0.10 & 0.13 & 0.08 & -0.23 \\
\hline Age $<35$ & 308 & $0.32^{\star *}$ & -0.05 & $-0.43^{\star \star}$ & -0.20 & 0.24 & 0.19 & -0.07 \\
\hline Age 35-64 & 556 & -0.06 & $-0.32^{\star}$ & 0.12 & 0.07 & -0.04 & 0.10 & 0.13 \\
\hline Age 65+ & 202 & $-0.34^{*}$ & $0.58^{\star \star}$ & $0.38^{\star *}$ & 0.15 & $-0.25^{\star}$ & $-0.42^{\star \star}$ & -0.11 \\
\hline \multicolumn{9}{|l|}{ Region and ethnicity } \\
\hline Auckland & 353 & -0.05 & 0.00 & -0.18 & 0.01 & -0.02 & -0.04 & $0.27^{\star}$ \\
\hline European & 783 & -0.16 & $0.39^{\star \star}$ & $0.42^{\star \star}$ & -0.07 & $-0.42^{\star \star}$ & $-0.28^{\star \star}$ & 0.12 \\
\hline Māori & 160 & 0.06 & -0.20 & 0.07 & -0.18 & $0.65^{\star \star}$ & 0.05 & $-0.44^{*}$ \\
\hline Pacific & 70 & $0.52^{\star \star}$ & $-0.60^{\star \star}$ & $-0.50^{\star \star}$ & $-0.51^{\star \star}$ & $0.80^{\star *}$ & 0.12 & 0.18 \\
\hline Asian & 128 & 0.06 & -0.29 & $-0.69^{\star \star}$ & $0.36^{*}$ & 0.30 & $0.37^{\star \star}$ & -0.13 \\
\hline \multicolumn{9}{|c|}{ Highest education and employment status } \\
\hline Secondary school & 340 & -0.03 & -0.13 & 0.19 & 0.19 & -0.15 & $0.31^{\star \star}$ & $-0.39^{*}$ \\
\hline Degree & 466 & 0 & $0.30^{*}$ & $-0.22^{*}$ & -0.16 & 0.11 & -0.17 & 0.14 \\
\hline Full-time job & 558 & 0.10 & -0.02 & -0.18 & -0.04 & -0.28 & 0.11 & $0.30^{*}$ \\
\hline \multicolumn{9}{|l|}{ Household income } \\
\hline$<\$ 50,000$ & 368 & -0.21 & $-0.30^{*}$ & 0.06 & $0.27^{*}$ & $0.42^{\star *}$ & 0.08 & $-0.31^{\star \star}$ \\
\hline$\$ 50,000-\$ 100,000$ & 426 & 0.06 & 0.05 & 0.04 & $-0.25^{\star}$ & -0.02 & 0.07 & 0.04 \\
\hline$>\$ 100,000$ & 272 & 0.17 & 0.29 & -0.12 & 0.00 & $-0.48^{\star \star}$ & -0.18 & $0.32^{*}$ \\
\hline \multicolumn{9}{|c|}{ Confidence about having enough money to live comfortably in retirement, and KiwiSaver membership } \\
\hline Not confident & 86 & $-0.58^{\star \star}$ & $-0.67^{\star \star}$ & 0.11 & $0.39^{*}$ & $1.14^{\star *}$ & -0.15 & -0.25 \\
\hline Very confident & 183 & $0.43^{\star \star}$ & $0.64^{\star \star}$ & $-0.37^{\star \star}$ & -0.17 & $-0.43^{*}$ & $0.30^{*}$ & -0.41 \\
\hline KiwiSaver & 701 & 0.03 & -0.22 & -0.13 & -0.22 & -0.30 & -0.02 & $0.85^{\star *}$ \\
\hline No KiwiSaver & 365 & -0.03 & 0.22 & 0.13 & 0.22 & 0.30 & 0.02 & $-0.85^{\star \star}$ \\
\hline
\end{tabular}

Notes: Each statistic is the difference in the mean preference rank for the identified subgroup with all people not in that subgroup. A negative number means the mean rank is lower (more important) for the subgroup. $\left.A^{*}{ }^{* *}\right)$ indicates the hypothesis that the two groups have the same distribution of preferences can be rejected at the 5 per cent (1 per cent) significance level, using a Wilcoxon-Mann-Whitney nonparametric test.

Source: Authors' calculations derived from the survey responses. 
Table 5. Fractional multinomial logit estimates of the effect of sociodemographic variables on the relative ranking of different policy criteria

\begin{tabular}{|c|c|c|c|c|c|c|c|}
\hline & $\begin{array}{c}1 \\
\text { Pension } \\
\text { amount }\end{array}$ & $\begin{array}{c}2 \\
\text { Age } \\
65 / 67\end{array}$ & $\begin{array}{l}3 \\
\text { Current } \\
\text { taxes }\end{array}$ & $\begin{array}{l}\quad 4 \\
\text { Future } \\
\text { taxes }\end{array}$ & $\begin{array}{l}\quad 5 \\
\text { Universality/ } \\
\text { means tests }\end{array}$ & $\begin{array}{c}6 \\
\text { Wealth } \\
\text { amount }\end{array}$ & $\begin{array}{c}7 \\
\text { Flexible } \\
\text { savings }\end{array}$ \\
\hline $\begin{array}{l}\text { Upper North Island } \\
\text { excl. Auckland } \\
\text { (ref: Auckland) }\end{array}$ & $\begin{array}{r}0.004 \\
(0.006)\end{array}$ & $\begin{array}{r}0.002 \\
(0.007)\end{array}$ & $\begin{array}{r}0.006 \\
(0.005)\end{array}$ & $\begin{array}{r}0.002 \\
(0.005)\end{array}$ & $\begin{array}{l}-0.008 \\
(0.007)\end{array}$ & $\begin{array}{r}0.004 \\
(0.005)\end{array}$ & $\begin{array}{l}-0.009 \\
(0.007)\end{array}$ \\
\hline $\begin{array}{l}\text { Lower North Island } \\
\text { (ref: Auckland) }\end{array}$ & $\begin{array}{r}0.006 \\
(0.005)\end{array}$ & $\begin{array}{r}0.002 \\
(0.006) \\
\end{array}$ & $\begin{array}{l}-0.001 \\
(0.005) \\
\end{array}$ & $\begin{array}{l}-0.006 \\
(0.005) \\
\end{array}$ & $\begin{array}{r}0.002 \\
(0.007) \\
\end{array}$ & $\begin{array}{l}-0.003 \\
(0.005) \\
\end{array}$ & $\begin{array}{r}0.000 \\
(0.006)\end{array}$ \\
\hline $\begin{array}{l}\text { South Island } \\
\text { (ref: Auckland) }\end{array}$ & $\begin{array}{l}-0.006 \\
(0.005)\end{array}$ & $\begin{array}{l}-0.009 \\
(0.006)\end{array}$ & $\begin{array}{r}0.003 \\
(0.005)\end{array}$ & $\begin{array}{r}0.006 \\
(0.005)\end{array}$ & $\begin{array}{r}0.008 \\
(0.007)\end{array}$ & $\begin{array}{r}0.002 \\
(0.005)\end{array}$ & $\begin{array}{l}-0.003 \\
(0.006)\end{array}$ \\
\hline $\begin{array}{l}\text { Male } \\
\text { (ref: Female) }\end{array}$ & $\begin{array}{l}-0.007 \\
(0.004)\end{array}$ & $\begin{array}{r}0.007 \\
(0.005)\end{array}$ & $\begin{array}{l}-0.003 \\
(0.004)\end{array}$ & $\begin{array}{r}0.004 \\
(0.004)\end{array}$ & $\begin{array}{r}0.000 \\
(0.005)\end{array}$ & $\begin{array}{l}-0.005 \\
(0.004)\end{array}$ & $\begin{array}{r}0.004 \\
(0.005)\end{array}$ \\
\hline $\begin{array}{l}\text { 35-64 years } \\
\text { (ref: <35 years) }\end{array}$ & $\begin{array}{r}-0.013 \\
(0.005)^{\star} \\
\end{array}$ & $\begin{array}{l}-0.005 \\
(0.006) \\
\end{array}$ & $\begin{array}{r}0.012 \\
(0.005)^{\star} \\
\end{array}$ & $\begin{array}{r}0.007 \\
(0.005) \\
\end{array}$ & $\begin{array}{r}0.005 \\
(0.007) \\
\end{array}$ & $\begin{array}{l}-0.008 \\
(0.005) \\
\end{array}$ & $\begin{array}{r}0.002 \\
(0.006) \\
\end{array}$ \\
\hline $\begin{array}{l}65+\text { years } \\
\text { (ref: <35 years) }\end{array}$ & $\begin{array}{r}-0.033 \\
(0.009)^{\star}\end{array}$ & $\begin{array}{r}0.030 \\
(0.012)^{*}\end{array}$ & $\begin{array}{r}0.028 \\
(0.009)^{\star}\end{array}$ & $\begin{array}{r}0.003 \\
(0.009)\end{array}$ & $\begin{array}{l}-0.008 \\
(0.012)\end{array}$ & $\begin{array}{l}-0.036 \\
(0.008)^{*}\end{array}$ & $\begin{array}{r}0.016 \\
(0.011) \\
\end{array}$ \\
\hline $\begin{array}{l}\text { NZ European and Māori } \\
\text { (ref: NZ European only) }\end{array}$ & $\begin{array}{r}0.010 \\
(0.009) \\
\end{array}$ & $\begin{array}{r}0.009 \\
(0.011) \\
\end{array}$ & $\begin{array}{l}-0.004 \\
(0.007) \\
\end{array}$ & $\begin{array}{l}-0.013 \\
(0.007) \\
\end{array}$ & $\begin{array}{r}0.019 \\
(0.011) \\
\end{array}$ & $\begin{array}{l}-0.015 \\
(0.008) \\
\end{array}$ & $\begin{array}{l}-0.007 \\
(0.011) \\
\end{array}$ \\
\hline $\begin{array}{l}\text { Māori only } \\
\text { (ref: NZ European only) }\end{array}$ & $\begin{array}{r}0.005 \\
(0.011) \\
\end{array}$ & $\begin{array}{l}-0.011 \\
(0.012) \\
\end{array}$ & $\begin{array}{r}0.003 \\
(0.008) \\
\end{array}$ & $\begin{array}{r}0.002 \\
(0.008) \\
\end{array}$ & $\begin{array}{r}0.002 \\
(0.012)\end{array}$ & $\begin{array}{r}0.012 \\
(0.008) \\
\end{array}$ & $\begin{array}{l}-0.013 \\
(0.012)\end{array}$ \\
\hline $\begin{array}{l}\text { Chinese only } \\
\text { (ref: NZ European only) }\end{array}$ & $\begin{array}{r}-0.002 \\
(0.01) \\
\end{array}$ & $\begin{array}{l}-0.003 \\
(0.011)\end{array}$ & $\begin{array}{r}-0.020 \\
(0.009)^{*}\end{array}$ & $\begin{array}{r}0.006 \\
(0.009) \\
\end{array}$ & $\begin{array}{r}0.003 \\
(0.011) \\
\end{array}$ & $\begin{array}{r}0.011 \\
(0.009) \\
\end{array}$ & $\begin{array}{l}0.005 \\
(0.01)\end{array}$ \\
\hline $\begin{array}{l}\text { Pacific only } \\
\text { (ref: NZ European only) }\end{array}$ & $\begin{array}{r}0.015 \\
(0.011) \\
\end{array}$ & $\begin{array}{r}0.006 \\
(0.013) \\
\end{array}$ & $\begin{array}{r}-0.025 \\
(0.01)^{\star}\end{array}$ & $\begin{array}{l}-0.011 \\
(0.009)\end{array}$ & $\begin{array}{r}0.007 \\
(0.013) \\
\end{array}$ & $\begin{array}{l}0.003 \\
(0.01) \\
\end{array}$ & $\begin{array}{r}0.004 \\
(0.013) \\
\end{array}$ \\
\hline $\begin{array}{l}\text { Other } \\
\text { (ref: NZ European only) }\end{array}$ & $\begin{array}{r}0.004 \\
(0.006) \\
\end{array}$ & $\begin{array}{l}-0.027 \\
(0.007)^{\star}\end{array}$ & $\begin{array}{l}-0.009 \\
(0.006)\end{array}$ & $\begin{array}{r}0.009 \\
(0.006) \\
\end{array}$ & $\begin{array}{r}0.018 \\
(0.008)^{*} \\
\end{array}$ & $\begin{array}{r}0.005 \\
(0.006) \\
\end{array}$ & $\begin{array}{r}0.000 \\
(0.007) \\
\end{array}$ \\
\hline $\begin{array}{l}\text { Other post-secondary } \\
\text { school qualifications } \\
\text { (ref: School qualification } \\
\text { or less) }\end{array}$ & $\begin{array}{l}-0.002 \\
(0.005)\end{array}$ & $\begin{array}{r}0.003 \\
(0.007)\end{array}$ & $\begin{array}{l}-0.001 \\
(0.005)\end{array}$ & $\begin{array}{l}-0.006 \\
(0.005)\end{array}$ & $\begin{array}{r}0.003 \\
(0.007)\end{array}$ & $\begin{array}{r}-0.013 \\
(0.005)^{\star}\end{array}$ & $\begin{array}{r}0.015 \\
(0.006)^{*}\end{array}$ \\
\hline $\begin{array}{l}\text { University degree } \\
\text { or equivalent } \\
\text { (ref: School qualification } \\
\text { or less) }\end{array}$ & $\begin{array}{l}-0.001 \\
(0.005)\end{array}$ & $\begin{array}{r}0.013 \\
(0.006)^{*}\end{array}$ & $\begin{array}{l}-0.002 \\
(0.004)\end{array}$ & $\begin{array}{l}-0.008 \\
(0.004)\end{array}$ & $\begin{array}{r}0.010 \\
(0.006)\end{array}$ & $\begin{array}{r}-0.015 \\
(0.005)^{\star}\end{array}$ & $\begin{array}{r}0.002 \\
(0.006)\end{array}$ \\
\hline $\begin{array}{l}\text { Not working } \\
\text { (ref: Working) }\end{array}$ & $\begin{array}{r}0.001 \\
(0.006) \\
\end{array}$ & $\begin{array}{r}0.005 \\
(0.007) \\
\end{array}$ & $\begin{array}{r}0.001 \\
(0.005) \\
\end{array}$ & $\begin{array}{r}0.002 \\
(0.005) \\
\end{array}$ & $\begin{array}{r}0.003 \\
(0.007) \\
\end{array}$ & $\begin{array}{c}-0.011 \\
(0.005)^{\star}\end{array}$ & $\begin{array}{l}-0.001 \\
(0.007) \\
\end{array}$ \\
\hline $\begin{array}{l}\text { Retired } \\
\text { (ref: Working) }\end{array}$ & $\begin{array}{l}0.010 \\
(0.01)\end{array}$ & $\begin{array}{r}-0.006 \\
(0.01)\end{array}$ & $\begin{array}{l}-0.013 \\
(0.008)\end{array}$ & $\begin{array}{r}0.003 \\
(0.008)\end{array}$ & $\begin{array}{l}-0.010 \\
(0.011)\end{array}$ & $\begin{array}{r}0.006 \\
(0.008)\end{array}$ & $\begin{array}{r}0.010 \\
(0.011)\end{array}$ \\
\hline $\begin{array}{l}\$ 30,001-\$ 50,000 \\
\text { (ref: } \$ 30,000 \text { or less) }\end{array}$ & $\begin{array}{r}0.001 \\
(0.008)\end{array}$ & $\begin{array}{l}0.009 \\
(0.01)\end{array}$ & $\begin{array}{l}-0.007 \\
(0.006) \\
\end{array}$ & $\begin{array}{l}-0.002 \\
(0.006) \\
\end{array}$ & $\begin{array}{r}0.000 \\
(0.008) \\
\end{array}$ & $\begin{array}{l}-0.003 \\
(0.007) \\
\end{array}$ & $\begin{array}{r}0.003 \\
(0.009) \\
\end{array}$ \\
\hline $\begin{array}{l}\$ 50,001-\$ 70,000 \\
\text { (ref: } \$ 30,000 \text { or less) }\end{array}$ & $\begin{array}{r}0.000 \\
(0.008)\end{array}$ & $\begin{array}{r}0.020 \\
(0.01)^{*}\end{array}$ & $\begin{array}{r}0.000 \\
(0.006)\end{array}$ & $\begin{array}{l}-0.009 \\
(0.006)\end{array}$ & $\begin{array}{l}-0.010 \\
(0.008)\end{array}$ & $\begin{array}{l}-0.009 \\
(0.007)\end{array}$ & $\begin{array}{r}0.007 \\
(0.009)\end{array}$ \\
\hline $\begin{array}{l}\$ 70,001-\$ 100,000 \\
\text { (ref: } \$ 30,000 \text { or less) }\end{array}$ & $\begin{array}{r}0.002 \\
(0.008)\end{array}$ & $\begin{array}{r}0.022 \\
(0.01)^{*}\end{array}$ & $\begin{array}{l}-0.003 \\
(0.007)\end{array}$ & $\begin{array}{l}-0.009 \\
(0.006)\end{array}$ & $\begin{array}{r}-0.016 \\
(0.008)^{\star}\end{array}$ & $\begin{array}{r}-0.014 \\
(0.006)^{*}\end{array}$ & $\begin{array}{r}0.019 \\
(0.009)^{\star}\end{array}$ \\
\hline
\end{tabular}




\begin{tabular}{|c|c|c|c|c|c|c|c|}
\hline & $\begin{array}{c}1 \\
\text { Pension } \\
\text { amount }\end{array}$ & $\begin{array}{c}2 \\
\text { Age } \\
65 / 67\end{array}$ & $\begin{array}{c}3 \\
\text { Current } \\
\text { taxes }\end{array}$ & $\begin{array}{c}4 \\
\text { Future } \\
\text { taxes }\end{array}$ & $\begin{array}{c}5 \\
\text { Universality/ } \\
\text { means tests }\end{array}$ & $\begin{array}{c}6 \\
\text { Wealth } \\
\text { amount }\end{array}$ & $\begin{array}{c}7 \\
\text { Flexible } \\
\text { savings }\end{array}$ \\
\hline $\begin{array}{l}\$ 100,001 \text { or more } \\
\text { (ref: } \$ 30,000 \text { or less) }\end{array}$ & $\begin{array}{r}0.003 \\
(0.008)\end{array}$ & $\begin{array}{r}0.025 \\
(0.011)^{\star}\end{array}$ & $\begin{array}{l}-0.004 \\
(0.007)\end{array}$ & $\begin{array}{l}-0.003 \\
(0.007)\end{array}$ & $\begin{array}{l}-0.023 \\
(0.008)^{\star}\end{array}$ & $\begin{array}{l}-0.019 \\
(0.007)^{\star}\end{array}$ & $\begin{array}{r}0.022 \\
(0.01)^{\star}\end{array}$ \\
\hline $\begin{array}{l}\text { De facto relationship } \\
\text { (ref: Married/civil union) }\end{array}$ & $\begin{array}{l}-0.005 \\
(0.006) \\
\end{array}$ & $\begin{array}{r}0.003 \\
(0.007) \\
\end{array}$ & $\begin{array}{r}-0.002 \\
(0.005) \\
\end{array}$ & $\begin{array}{r}0.004 \\
(0.005) \\
\end{array}$ & $\begin{array}{r}0.001 \\
(0.007) \\
\end{array}$ & $\begin{array}{l}-0.001 \\
(0.006) \\
\end{array}$ & $\begin{array}{r}0.000 \\
(0.007) \\
\end{array}$ \\
\hline $\begin{array}{l}\text { Single } \\
\text { (ref: Married/civil union) }\end{array}$ & $\begin{array}{l}-0.004 \\
(0.006) \\
\end{array}$ & $\begin{array}{r}0.011 \\
(0.007) \\
\end{array}$ & $\begin{array}{l}-0.002 \\
(0.005) \\
\end{array}$ & $\begin{array}{l}-0.002 \\
(0.005) \\
\end{array}$ & $\begin{array}{r}0.002 \\
(0.007) \\
\end{array}$ & $\begin{array}{l}-0.007 \\
(0.005) \\
\end{array}$ & $\begin{array}{r}0.004 \\
(0.006) \\
\end{array}$ \\
\hline $\begin{array}{l}\text { Have children } \\
\text { (ref: No children) }\end{array}$ & $\begin{array}{r}0.010 \\
(0.005)^{\star}\end{array}$ & $\begin{array}{l}-0.004 \\
(0.006)\end{array}$ & $\begin{array}{l}-0.002 \\
(0.004)\end{array}$ & $\begin{array}{l}-0.001 \\
(0.004)\end{array}$ & $\begin{array}{l}-0.001 \\
(0.006)\end{array}$ & $\begin{array}{r}0.005 \\
(0.004) \\
\end{array}$ & $\begin{array}{l}-0.008 \\
(0.005)\end{array}$ \\
\hline $\begin{array}{l}\text { Somewhat confident } \\
\text { (ref: Very confident) }\end{array}$ & $\begin{array}{l}-0.008 \\
(0.005)\end{array}$ & $\begin{array}{l}-0.010 \\
(0.007)\end{array}$ & $\begin{array}{r}0.008 \\
(0.006)\end{array}$ & $\begin{array}{r}0.004 \\
(0.005)\end{array}$ & $\begin{array}{r}0.011 \\
(0.008)\end{array}$ & $\begin{array}{l}-0.013 \\
(0.005)^{\star}\end{array}$ & $\begin{array}{r}0.008 \\
(0.007)\end{array}$ \\
\hline
\end{tabular}

Notes: The dependent variable is the criterion weight equal to the relative rank/28. A negative coefficient means that people with the particular socio-demographic variable consider the criterion to be important.

Source: Authors' calculations derived from the survey responses.

The results of the two approaches are broadly consistent. In the fractional multinomial logit model, many socio-demographic variables have a statistically significant effect on the mean rank of one or more criteria, but the effects tend to be small, less than one rank. For example, the estimated coefficient for people 65 and over on the 'pension size' criterion in Table 5 is -0.033 , indicating that a large pension is more important to people aged 65 and over than people aged under 35 . On average they give it a rank $0.9\left(=0.033^{*} 28\right)$ lower (i.e. more important). Typically, when a sociodemographic variable is statistically significant in the fractional multinomial logit model, that social-demographic subgroup has a mean rank vector that differs from the rest of the population by a statistically significant amount.

The results can be analysed in terms of the criteria that are important to particular socio-demographic groups (i.e. an analysis of the rows of Tables 4 and 5), or in terms of the socio-demographic characteristics that are associated with people who have strong views about each of the seven criteria (i.e. an analysis of the columns of Tables 4 and 5). Considering the rows first, three distinctive features associated with different socio-demographic factors stand out. First, people aged 65 and over have different preferences than people aged less than 65: they think it is more important to have a higher pension and more wealth in retirement; they are more opposed to means-testing and less opposed to increases in current taxes; and they are less concerned with keeping the age of eligibility at 65 . While these effects are statistically significant, they are relatively small, with average ranks differing by less than 0.6 and generally much less.

Secondly, people living in low-income households have a stronger preference for keeping the age of eligibility at 65 than other groups; they are also more opposed to compulsion but less concerned about means-testing or future tax rates. The same preferences are also shown by people who are not confident they will have enough 
money to live comfortably in retirement, but they are more strongly held. The latter group also expresses a stronger preference for means-testing and would like the size of the pension increased.

Thirdly, the results in Table 4 suggest there are differences in the preferences of different ethnic groups. New Zealanders with non-European ethnicity tend to be more concerned with keeping the age of eligibility at 65, are more opposed to increases in current taxes, and are more supportive of means-tested pensions than New Zealanders with European ethnicity. The differences are most marked for Pacific people. However, it appears that these differences mainly reflect the different age and income characteristics of non-European New Zealanders, as ethnicity is not an important factor in the fractional multinomial logit regressions. Once age and income are taken into account in the fractional multinomial regressions, the results showing that Pacific people have relatively strong preferences for higher pensions, lower taxes, an earlier eligibility age and means-testing no longer hold.

The results can be restated by highlighting the socio-demographic factors that are associated with each of the survey criteria (i.e. the columns of Table 4 and 5). There are three significant results.

First, an increase in the age of eligibility tends to be supported by higher-income people, those of European ethnicity, those who are more confident about having enough money to live comfortably in retirement, and people 65 and over. Secondly, opposition to means-testing is higher among higher-income people, those of European ethnicity, those who are more confident about having a comfortable retirement, and people aged 65 and over. Thirdly, saving flexibility rather than compulsion is most strongly preferred by low-income people, those with fewest educational qualifications and - most strongly - by those who are not members of the KiwiSaver scheme. The former two groups are the people most likely to need to reduce consumption if there were a compulsory saving scheme, and thus those most likely to be inconvenienced by a compulsory saving scheme.

While these differences in the preferences of different socio-demographic groups are statistically significant, they are not typically large. For example, while universality is more important to people over 65 than under 65 , it is the single most important criterion to both groups, and the mean rank for this criterion for those over 65 is only 0.25 less than for those under 65 (2.94 versus 3.20 , on a scale of $1-7)$. In the same way, while people over 65 think it is more important to increase the size of the pension than those under 65 , the difference between the two groups is only -0.34 (3.82 versus 4.16, on a scale of $1-7$ ). The small size of these effects is consistent with the international literature, and suggests that socio-demographic characteristics are not the dominant determinants of preferences over retirement income policies. 
A feature of the international literature is the evidence that people have little tendency to answer surveys in a particularly self-interested manner. The finding that survey results only show weak evidence of self-interested behaviour was made using US data by Ponza, Duncan, Corcoran and Groskind (1988) and Sears and Funk (1990), and confirmed by Evans and Kelley (2004) and Lynch and Myrskylä (2009) using Australian and European data. These papers show that a respondent's attitudes, not his or her income or age, are the most important determinants of retirement income survey responses. Boeri et al. (2002) argue there is somewhat stronger evidence of self-interested behaviour in two Italian and German surveys, but even in these surveys age and income provide little explanatory power of individual preferences.

The results from our survey show more evidence of self-interested responses than the results from other surveys, even if the size of the effects is small. In particular, we find a small tendency for people in lower-income households to oppose compulsion, to favour means-testing, and to favour a lower entitlement age. We also find a small tendency for people over 65 to favour higher pensions and a higher age of eligibility, and to be more opposed to means-testing. It is not clear why these results are more pronounced than those in other surveys, but it may reflect a more accurate approach to estimating preference rankings. It should be noted, however, that a majority of all demographic subgroups would be prepared to raise taxes immediately if that would reduce taxes on future generations, a result opposed to the notion that people respond in self-interested ways.

\subsection{Cluster analysis}

To investigate the diversity of preferences further, we used Lloyd's (1982) algorithm to sort the respondents into five endogenously determined preference clusters. Each person is allocated to the cluster that has the nearest mean preference vector; as members of the cluster will have greater affinity with each other's views than with members of other clusters, the mean Spearman rank correlations for the clusters are much higher than the mean rank correlation estimated for the whole sample, and range from 0.39 to 0.61 . Each cluster contains between 13 per cent and 27 per cent of the respondents. We chose five clusters, as the estimated partitions in this case were stable. ${ }^{9}$

The five clusters are shown in Table 6 . They differ largely by the way their members rank the age of eligibility, universality/means-testing, and saving flexibility/ compulsion criteria. With one exception, each of these three criteria are ranked 1 or 2 (most important) or 6 or 7 (least important) in each cluster. People in the two largest clusters (cluster 1 - 'Status quo plus compulsion' and cluster 2 'Raise age plus compulsion') concur that universality is the most important and that saving

9 The results of the cluster analysis are similar if people are allocated to four clusters, but the estimated partitions for three or for six cluster groups were not stable. 
flexibility is the least important criteria, but disagree as to whether increasing the age of eligibility from 65 to 67 is the second most important or the second least important criterion. People in cluster 3 ('Means-tested redistribution') favour the introduction of a means-test to fund higher pension payments, and also support compulsion. People in cluster 4 ('Pension minimalists') favour the least government intervention - they are against means-testing and compulsion, and want the age of eligibility increased. The fifth cluster ('No compulsion') is the smallest and least cohesive cluster and comprises people who are unified because they strongly favour saving flexibility rather than compulsion.

Table 6. The five cluster groups

\begin{tabular}{|l|r|r|r|r|r|}
\hline & $\begin{array}{c}\text { Cluster 1 } \\
\text { Status quo + } \\
\text { compulsion }\end{array}$ & $\begin{array}{c}\text { Cluster 2 } \\
\text { Raise age + } \\
\text { compulsion }\end{array}$ & $\begin{array}{c}\text { Cluster 3 } \\
\text { Means-tested } \\
\text { redistribution }\end{array}$ & $\begin{array}{c}\text { Cluster 4 } \\
\text { Pension } \\
\text { minimalists }\end{array}$ & $\begin{array}{c}\text { Cluster 5 } \\
\text { No } \\
\text { compulsion }\end{array}$ \\
\hline Central vector & $\{6243157\}$ & $\{4652137\}$ & $\{2451637\}$ & $\{5743162\}$ & $\{4253761\}$ \\
\hline $\begin{array}{l}\text { Sample fraction } \\
\text { (s. dev) }\end{array}$ & $\begin{array}{r}27 \% \\
(0.3 \%)\end{array}$ & $\begin{array}{r}24 \% \\
(0.9 \%)\end{array}$ & $\begin{array}{r}18 \% \\
(0.7 \%)\end{array}$ & $\begin{array}{r}17 \% \\
(0.7 \%)\end{array}$ & $\begin{array}{r}14 \% \\
(0.7 \%)\end{array}$ \\
\hline $\begin{array}{l}\text { Mean Spearman } \\
\text { correlation }\end{array}$ & 0.56 & 0.61 & 0.48 & 0.44 & 0.39 \\
\hline Mean minimum distance & 16.6 & 14.1 & 20.6 & 19.0 & 21.7 \\
\hline
\end{tabular}

Source: Authors' calculations derived from the survey responses.

Can membership of a cluster be predicted from a person's socio-demographic characteristics? In general, no. For most population subgroups it is not possible to reject the hypothesis that the subgroup has the same distribution across the clusters as the overall sample. There are two main exceptions. First, non-Europeans, particularly Māori, are more likely to be in cluster 5 ('No compulsion') and less likely to be in cluster 2 ('Raise age plus compulsion') than Europeans; 23 per cent of Māori were in cluster 5 relative to the national average of 14 per cent. Secondly, respondents in high-income households are 4 percentage points less likely to be in cluster 3 ('Means-tested redistribution') and cluster 5 ('No compulsion') than the general public.

In contrast, there are significant differences in the allocation across clusters of the groups that self-identify in terms of their level of confidence that they will have a comfortable retirement. People who do not expect to be comfortable are significantly more likely to be in clusters 3 and 5 ('Means-tested redistribution' and 'No compulsion') and less likely to be in cluster 4 ('Pension minimalists'). Those who are confident they will be comfortable in retirement are much more likely to be in cluster 4 ('Pension minimalists') and much less likely to be in cluster 3 ('Meanstested redistribution'). These differences reinforce the finding that differences based on non-observable characteristics tend to be larger than differences based on observable characteristics. 


\section{Policy choices}

A key advantage of the multi-criteria decision analysis technique associated with the 1000Minds software is that the estimates of individual preferences can be used to evaluate how individuals will rank different policy packages. This evaluation is possible because the preference relationships of each respondent are used to estimate a cardinal utility function. The policy evaluations are made by (i) categorising each policy according to the survey criteria; (ii) using the respondent's estimated preference weights to estimate his or her utility corresponding to the outcomes of each policy; and (iii) ranking each policy option by the utility scores.

In this section we estimate New Zealanders' preferences over three fiscally neutral retirement income policies that have been extensively discussed in New Zealand. The first policy, 'PAYGO65' is the continuation of New Zealand Superannuation in its current form. It has the following features: (i) The pension is universal, and not means-tested. All people satisfying residency criteria receive the pension when they turn 65. (ii) The weekly payment for single recipients is approximately $\$ 360$ in 2014-15, and adjusted for wage inflation. (iii) The pension is largely funded on a pay-as-you-go basis. No tax increases are required to finance current payments, but taxes will have to be increased to finance payments as the population ages. (According to Treasury projections, taxes will need to increase by 4.6 per cent of taxable income by 2050, a number we use as a proxy for the tax on future generations.) The second policy, 'PAYGO67' is similar but the age of eligibility for people born after 1953 is increased to 67 from 2020. No change in current taxes is necessary, but the taxes needed to pay for the pension will only increase by 3.5 per cent of taxable income by 2050 . The third policy, 'SAYGO65', keeps the age of eligibility and the structure of pension payments the same as PAYGO65, but a tax surcharge equal to 2 per cent of taxable income is immediately imposed and placed in a sovereign wealth fund, the New Zealand Superannuation Fund. ${ }^{10}$ The additional contributions are assumed to cease after 30 years, at which point the ongoing earnings of the fund will reduce the increase in future taxes to 2.6 per cent of taxable income. ${ }^{11}$ The differences in the three policies are shown in Table 7.

10 The New Zealand Superannuation Fund was established in 2002 for this purpose.

11 We assume (i) 2 per cent of taxable income is added to the New Zealand Superannuation Fund each year; (ii) income increases at 2 per cent per year; and (iii) the Fund compounds at a 4 per cent real rate of return. After 30 years the accumulated Fund will have increased by 84 per cent of the contemporaneous level of income, and will produce ongoing returns that allow taxes to be reduced by 2 per cent of contemporaneous income. These assumptions satisfy the wording of the fourth criterion. If the rate of return is lower than 4 per cent real, the contribution period would have to be lengthened. As a 4 per cent rate of return is low by historic standards the contribution period could be shorter than 30 years. 
Table 7. Three possible retirement income policies

\begin{tabular}{|l|r|r|r|}
\hline & Age of eligibility & Tax increase in 2015 & Tax increase in 2050 \\
\hline PAYG065 & 65 & $0 \%$ & $4.6 \%$ \\
\hline PAYG067 & 67 & $0 \%$ & $3.5 \%$ \\
\hline SAYG065 & 65 & $2 \%$ & $2.6 \%$ \\
\hline
\end{tabular}

Source: Authors' summary of New Zealand retirement policies.

When the policy outcomes do not exactly coincide with the survey categories, the utility function is interpolated. ${ }^{12}$ The accuracy of the rankings increases with the number of categories in each criterion, but is highest when the policy outcomes exactly coincide with the survey categories, for then interpolation of the utility function is unnecessary. For this reason, the comparison of the SAYGO65 and the PAYGO65 policies is most accurate as the differences in the two policies (the differences in the current and future tax rates) exactly coincide with the differences in the survey tax criteria categories.

Table 8 shows the proportion of the sample that ranks each of the three policy options the highest, second highest, and lowest. The table shows that 58 per cent of respondents would obtain the greatest utility from the SAYGO65 policy, 26 per cent from the current PAYGO65 policy, but only 16 per cent from the PAYGO67 policy. Furthermore, only 16 per cent of the population would have the lowest utility from the SAYGO65 policy, whereas 28 per cent and 56 per cent would have the lowest utility from the PAYGO65 and PAYGO67 policies respectively. These results clearly indicate that, judged in terms of their own preferences, the policy option of raising the age of eligibility is the policy least preferred by the largest number of people and most preferred by the smallest number. In contrast, a policy of maintaining the age of eligibility at 65 and prefunding some future New Zealand Superannuation payments is the policy most preferred by the largest number of people and least preferred by the fewest. These results reflect the high rank most respondents place on the importance of avoiding large tax increases on future generations: 65 per cent of all respondents indicated they would accept an increase in current taxes equal to 2 per cent of taxable income if it would reduce taxes on the next generation by a similar amount. This preference ranking, which was shared by almost all population subgroups, is one of the strongest findings of the survey.

12 For example, the utility corresponding to a 4.6 per cent increase in future taxes is calculated by multiplying the weights associated with a 3 per cent and a 5 per cent increase by 0.2 and 0.8 respectively. 
Table 8. Welfare ranking of different policies

\begin{tabular}{|l|r|r|r|}
\hline & Highest ranking & Middle ranking & Lowest ranking \\
\hline PAYG065 & $26 \%$ & $46 \%$ & $28 \%$ \\
\hline PAYG067 & $16 \%$ & $28 \%$ & $56 \%$ \\
\hline SAYG065 & $58 \%$ & $26 \%$ & $16 \%$ \\
\hline
\end{tabular}

Note: The table shows the fraction of the population giving each policy the 1st, 2 nd or 3rd highest ranking.

Source: Authors' calculations derived from the survey responses.

Does this ranking differ across population subgroups? Given the earlier finding that there are only small differences in the preferences of most subgroups, it is not surprising that different population subgroups rank the policies in a very similar manner. The SAYGO65 policy is the most popular and the least unpopular policy option for all the population subgroups analysed, and the PAYGO67 policy is the least popular and most unpopular option. ${ }^{13}$ Unsurprisingly, however, the popularity of the policies varies substantially across the preference clusters. The PAYGO67 policy option is relatively popular with members of cluster 4 ('Pension minimalists') but with almost no-one else, and it is overwhelmingly the least popular choice with members of clusters 1 ('Status quo plus compulsion'), 3 ('Means-tested redistribution') and 5 ('No compulsion').

While we have only formally evaluated three policies, the advantage of this approach is that many others could be evaluated. For example, we could evaluate whether people would be willing to increase current and future tax rates to increase the size of the pension by $\$ 30$ per week, or we could analyse the effect of indexing future amounts of New Zealand Superannuation to the consumer price index rather than wages. It is also possible to evaluate how policies that provide people with a range of options might affect welfare. An example of such a policy is the so-called flexibleSuperannuation option, which is available in countries such as the United States that allows people to defer receiving a pension in exchange for receiving a larger amount. In a New Zealand context, we can evaluate the benefits of providing people with the option of receiving an extra $\$ 30$ per week if they delay taking a pension until age 67 , assuming that this was fiscally neutral. ${ }^{14}$ Our survey indicates that this option would be the preferred choice for 46 per cent of respondents, while the remaining 54 per cent would prefer current arrangements. This suggests that a policy that allowed people to choose when they got the pension would improve the welfare of 46 per cent of the population.

13 The Asian ethnicity group is the only population subgroup in which a majority of people did not rank the SAYGO65 policy as the most preferred, and even for this group it was still the single most preferred policy.

14 The policy could be evaluated if it were not fiscally neutral by calculating the changes in taxes needed to fund it. 


\section{Conclusion}

This paper investigates whether a multi-criteria decision-making survey can be used to help develop core public finance policy options, in this case retirement income policy. The answer is 'yes'. The survey provided detailed information about the relative importance of specific policy criteria. It shows, for example, that having a universal pension without a means-test is the most important issue for the greatest number ( 42 per cent) of respondents, while the least important issue for the largest number of respondents (38 per cent) is saving flexibility and compulsion. Respondents also revealed strong preferences about the timing of the taxes necessary to pay for pensions, with a large majority opposed to large tax increases on future generations. In contrast, there is considerable disagreement about the desirability of raising the age of eligibility from 65 to 67 , with equal numbers of people either strongly opposed to or unconcerned about the policy. All of these findings can be disaggregated by population subgroups. We show, for example, that while few people overall would be opposed to the introduction of a small compulsory saving scheme, there is more opposition from people living in low-income households and from Māori.

The results indicate that while preferences about retirement income are diverse, they depend only a little on observable characteristics such as age, education, income or ethnicity. Rather, New Zealanders' preferences reflect unobservable characteristics and people can be systematically grouped into clusters who share similar attitudes. Some of these attitudes appear to reflect their expectations about their level of comfort in retirement. However, it is likely that these attitudes also reflect deepseated philosophical approaches to life (Bowles and Gintis, 2000). For example, there seem to be an identifiable cluster of people united in a preference for minimalist government intervention into retirement income policy, and another that is keen on greater redistribution.

An advantage of this survey technique is that the relative merit of complex policy proposals can be evaluated on the basis of individual rather than average preferences. We used the technique to make an assessment of three retirement income policies at the heart of contemporary debates in New Zealand: the current policy, a variation in which the age of eligibility is raised by two years to reduce future tax obligations, and another variation in which current taxes are increased to reduce future tax obligations. By estimating individual preferences, we show that raising the age of eligibility by two years is the most preferred policy for the fewest number of people and the least preferred policy for the largest number. In contrast, a policy that raises current taxes to prevent even larger future tax is preferred by a majority of the population and, indeed, a majority of almost all population subgroups. 
Multi-criteria decision surveys, like other surveys, have some limitations. Surveys need to have enough criteria to capture the real-life complexity of an issue. Survey respondents must be able to understand the implications of different category levels of each criterion, and this may rule out many potential survey topics. Surveys are subject to framing biases, although to address framing concerns in future research it would be possible to use several differently framed surveys, possibly applied to smaller samples. Nonetheless, this survey provided an astonishing amount of information from a large number of people about the relative importance of several different aspects of retirement policies. Consequently, on the basis of the results obtained from this research, we believe the multi-criteria decision analysis approach has considerable potential to improve policy analysis and development.

\section{References}

Arrow, K. and Raynaud, H. (1986). Social choice and multicriterion decision making. Cambridge, Mass.: MIT Press.

Bartels, L. (2003). Is 'popular rule' possible? Polls, political psychology and democracy. The Brookings Review, 21(3), 12-15.

Belton, V. and Stewart, T. (2002). Multiple criteria decision analysis: An integrated approach. USA: Kluwer Academic Publishers.

Boeri, T., Boersch-Supan, A. and Tabellini, G. (2002). Pension reforms and the opinions of European citizens. American Economic Review Paper and Proceedings, 92(2), 396-401. doi.org/10.1257/000282802320191688.

Bowles, S. and Gintis, H. (2000). Reciprocity, self-interest, and the welfare state. The Nordic Journal of Political Economy, 26(January), 33-53.

Devlin, N.J. and Sussex, J. (2011). Incorporating multiple criteria in HTS: Methods and processes. London: Office of Health Economics Research.

Evans, M. and Kelley, J. (2004). Assessing age pension options: Public opinion in Australia 1994-2001 with comparisons to Finland and Poland (Melbourne Institute Working Paper 21/04). Melbourne: University of Melbourne.

Fourati, Y. and O'Donoghue, C. (2009). Eliciting individual preferences for pension reform (IZA DP 4479). Bonn: Institute for the Study of Labour.

Gamper, C. and Turcanu, C. (2007). On the governmental use of multi-criteria analysis. Ecological Economics, 62(2), 298-307. doi.org/10.1016/j.ecolecon.2007.01.010.

Hansen, P. and Ombler, F. (2008). A new method for scoring additive multi-attribute value models using pairwise rankings of alternatives. Journal of Multi-Criteria Decision Analysis, 15(3-4), 87-107. doi.org/10.1002/mcda.428. 
Lees-Marshment, J. (2015). The ministry of public input. New York: Palgrave MacMillan.

Li, L. and Schucany, W.R. (1975). Some properties of a test for concordance of two groups of rankings. Biometrika, 62(2), 417-423. doi.org/10.2307/2335382.

Lloyd, S.P. (1982). Least squares quantization in PCM. Information Theory, IEEE Transactions on information theory, 28(2), 129-137. doi.org/10.1109/tit.1982.1056489.

Lynch, J. and Myrskylä M. (2009). Always the third rail? Pension income and policy preferences in European democracies. Comparative Political Studies, 42(8), 1068-1097. doi.org/10.1177/0010414009331722.

Mardin, J. (1995). Analyzing and modeling rank data. London: Chapman and Hall.

Mendoza, G. and Martins, H. (2006). Multi-criteria decision analysis in natural resource management: A critical review of methods and new modelling paradigms. Forest Ecology and Management, 230(1), 1-22. doi.org/10.1016/j.foreco.2006.03.023.

Ombler, F. and Hansen, P. (2012). 1000Minds [software]. Retrieved from: www.1000minds. com.

Ponza, M., Duncan, G., Corcoran, M. and Groskind, F. (1988). The guns of autumn? Age differences in support for income transfers to the young and old. Public Opinion Quarterly, 52(4), 441-466. doi.org/10.1086/269124.

Sears, D. and Funk, C. (1990). The limited effect of economic self-interest on the political attitudes of the mass public. The Journal of Behavioral Economics, 19(3), 247-271. doi.org/10.1016/0090-5720(90)90030-b.

Van Els, P.J., Van den End, W.A. and Van Rooij, M.C. (2004). Pensions and public opinion: A survey among Dutch households. De Economist, 152(1), 101-116. 
This text is taken from Agenda, Volume 26-Number 1, 2019, edited by William Coleman, published 2019 by ANU Press, The Australian National University, Canberra, Australia.

doi.org/10.22459/AG.26.01.2019.02 